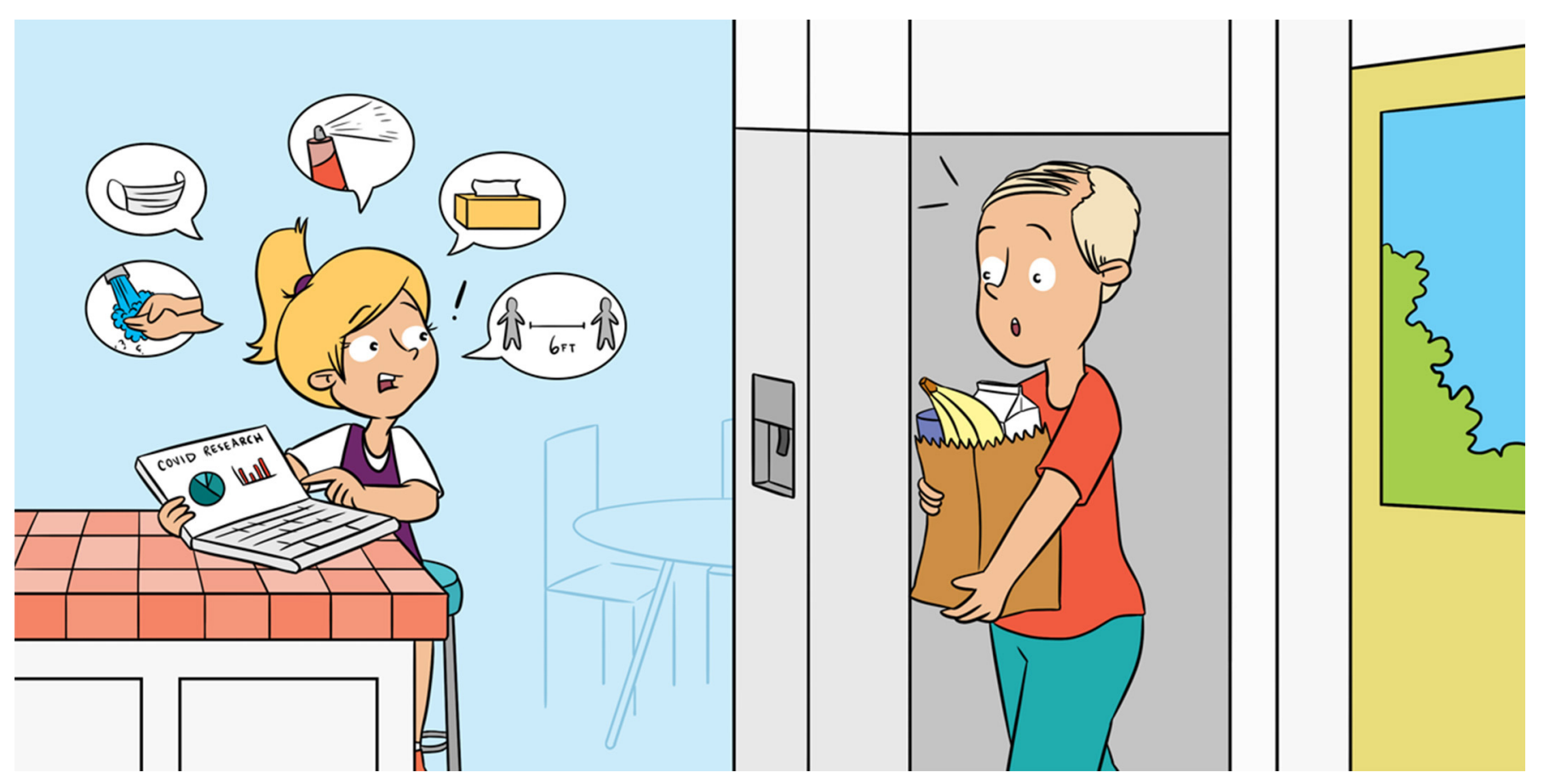

\title{
COVID-19, THE QUARANTINE-VIRUS DISEASE
}

\section{Hilde Stevens * and Marie Neunez}

Institute for Interdisciplinary Innovation in Healthcare (I3h), Faculty of Medicine-Solvay Brussels School, Economics \& Management, Université libre de Bruxelles, Brussels, Belgium

\section{YOUNG REVIEWER:}

CAROLINE AGE: 15
Since December 2019, the world has been facing an outbreak of a new Coronavirus, called SARS-CoV-2, causing a disease called COVID-19. The virus spreads through close contact and droplets created when we sneeze, cough, or speak. Luckily, when children get infected, they seem to only have mild symptoms, like fever and cough. Mainly people over 65 years old and people with other health conditions are most seriously affected by COVID-19. The disease causes infection of the lungs, blood, and digestive system. Increased hygiene, good ventilation of rooms, keeping a "social" distance of at least $1.5 \mathrm{~m}$ from those who do not live in your house, and staying at home are our best protection against spreading the virus. Currently, the best way to contain SARS-CoV-2 is through thorough testing for infections and quarantining infected patients and others who were in contact with the infected person before he/she got sick. A COVID-19 vaccine is also being developed! 


\section{ZOONOTIC}

Zoonotic is a term used to refer to a disease that can spread from animals to humans. A zoonosis is any disease or infection that is naturally transmissible from vertebrate animals to humans. Animals thus play an essential role in maintaining zoonotic infections in nature.

\section{PANDEMIC}

A pandemic is an epidemic (a sudden outbreak) that becomes very widespread and affects a whole region, a continent, or the world due to a susceptible population. A true pandemic causes a high degree of mortality (death).

\section{ACE2 RECEPTOR}

A molecule on the surface of cells in the lungs, arteries, heart, kidneys, and intestines that serves as an entry point into cells for some Coronaviruses.

\section{THE NEW CORONAVIRUS: THE BASICS}

SARS-CoV- 2 is the name of the youngest member of the Coronavirus family known to infect people (Figure 1). Its full name is severe acute respiratory syndrome-coronavirus-2. The virus causes severe infections of the lungs, blood, and digestive system. The disease SARS-CoV-2 causes is called COVID-19 (coronavirus disease 2019). SARS-CoV-1 (severe acute respiratory syndrome coronavirus-1) and MERS-CoV (Middle-East respiratory syndrome coronavirus), two other famous family members, also caused considerable human suffering and death-SARS in 2002 and MERS in 2012. Four other successful family members cause about a third of common colds [1, 2].

SARS-CoV-2 is a zoonotic virus, meaning that it jumped from an animal to a human. The virus' genetic similarity to bat coronaviruses explains why scientists believe that SARS-CoV-2 jumped from its original host, a bat, to a human. Since the first patient was diagnosed in Wuhan, China, this was thought to be the place of origin of the virus. However, scientists from different countries found traces of the virus in sewage water in early December, long before the first infected patient was diagnosed. This adds to evidence that the virus may have been circulating much earlier than thought. Coronavirus looks like a little ball (diameter $50-200 \mathrm{~nm}$, so tiny it is only detectable with a very powerful microscope) with crown-like spikes ("corona" means crown). The virus' outer layer consists of fatty particles that are easily destroyed when the virus comes into contact with soap [1, 2].

\section{HOW DID COVID-19 CAUSE A PANDEMIC?}

Zoonotic viruses have caused more and more outbreaks in the past few decades. A disease spreading over the whole world is called a pandemic [3]. But why did SARS-CoV-2 cause a pandemic like we have not seen in more than a century? Worldwide, almost 15 million people have been infected, and nearly 650,000 people have died from COVID-19 (as of 21/07/20) [4]. For a disease to become a pandemic, spreading around the world in just months and causing that much harm to people, it must be very contagious, but not too deadly.

All viruses need to hijack other cells to reproduce. That is their only goal: to survive and multiply themselves (Figure 2). SARS-CoV-2 spreads through close contact and the droplets we spread when we sneeze, cough, or speak. It can enter our bodies through our eyes, nose, or mouth. The virus can survive on various surfaces for hours, so people can get it on their hands and infect themselves by touching their faces, something we do on average 20 times per hour [1, 2].

Once inside the body, the crown-like spikes of SARS-CoV-2 attach to molecules called ACE2 receptors, which are found on many human cells. Using these receptors, the virus enters our cells and gives the cell 


\section{Figure 1}

\section{SARS-CoV-2 is the} newest member of the family of coronaviruses; it particularly likes to infect older and weaker people, but does not really like to infect children.

\section{THE CORONA FAMily GAllEry}
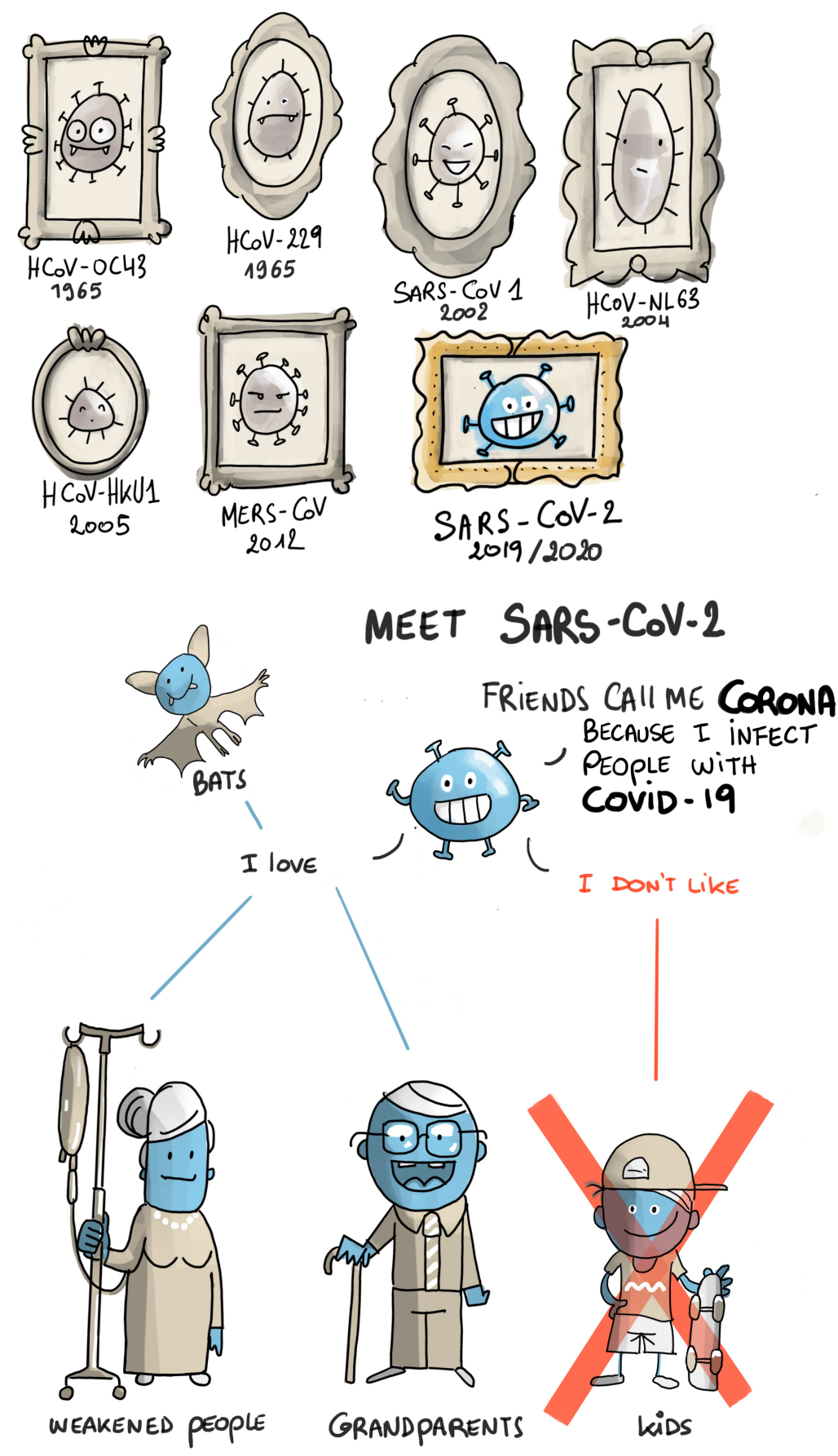

MR.LAPIN (C) 2020

instructions to produce numerous copies of itself, which can go on to invade more and more cells. As more cells get infected, this can lead to flu-like symptoms, such as cough, fever, and fatigue. Other symptoms 


\section{Figure 2}

Through attaching to the ACE 2 receptors, found on many human cells, the virus enters and gives the cell instructions to produce numerous copies of itself, so the virus can invade more and more cells.

\section{INCUBATION \\ PERIOD}

Time between the encounter with a pathogen (virus or other microorganism causing disease) and appearance of the first symptoms. During that time, the pathogen is multiplying in the body.

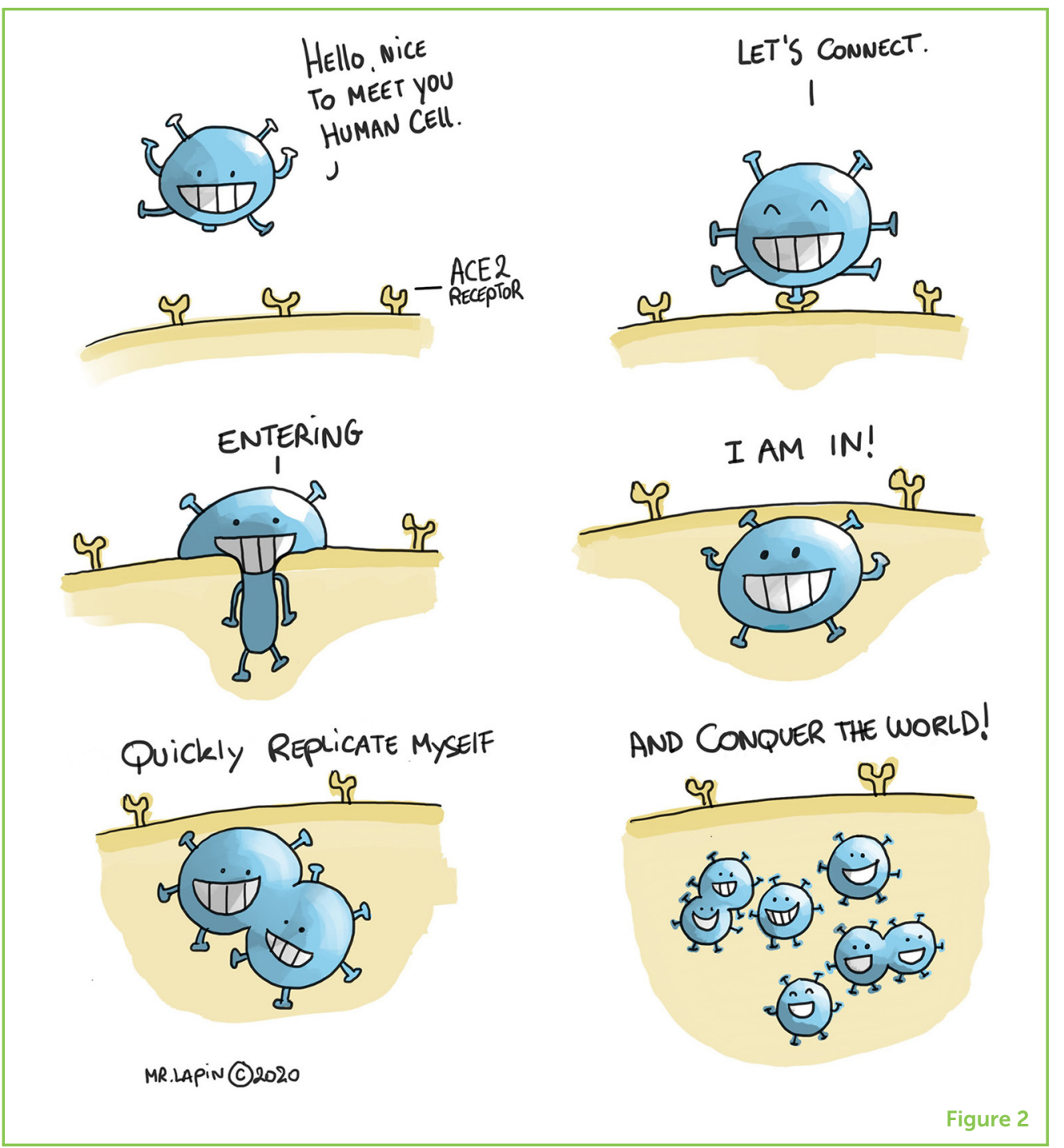

include shortness of breath, sore throat, loss of appetite, loss of sense of smell or taste, and diarrhea [1, 2].

However, it is possible to be infected with SARS-CoV-2 and to spread it without even having symptoms. When this virus first infects a human, it is silent for some time. This is called the incubation period and it can last up to 2 weeks. About 3 days before the first symptoms appear, infected people can spread the virus to others. When no measures are taken, they are likely to infect between 1 and 4 other people without knowing it. The newly infected people in turn will be able to infect more people, and so on. That is why the virus is so successful in causing a pandemic. The number of infected people doubles quite rapidly $[1,2]$.

\section{AM I AT RISK? AM I A RISK TO OTHERS?}

Research is ongoing, but we do know that children are at lower risk of severe infection and they are not the main people spreading the virus. 
Only a small portion of confirmed COVID-19 cases are in children. However, since children show no or only mild symptoms, they do not get tested as much as adults [1-3,5].

The older you get, the more you are at risk of developing serious symptoms from COVID-19, such as severe lung infection. People aged 65 and older, as well as people already suffering from other conditions like lung or heart disease, a weakened immune system, or diabetes, are more at risk. Research shows that men are more likely to get sick with COVID-19 than women are. This could be due to biological differences, or because they tend to smoke more often, or maybe even because they wash their hands less frequently $[1-3,5]$.

So, if children are less likely to get infected, do not develop severe symptoms as often, and might not spread the disease, then why did almost all schools close? At the start of the pandemic, little was known about SARS-CoV-2. Scientists and governments did not want to take any risks that might help the virus spread further. Schools, shops, and airports closed, non-essential contact between humans was avoided, and most people worked from home. Almost the whole world went in a so-called "lockdown," in which everybody stayed at home as much as possible. Only public services, such as hospitals, public transport, garbage collectors, and food shops continued working. Thanks to these strong governmental measures, the rate of infections slowed down, and hospitals were able to help the people who got really ill. This is what is meant by the term "flattening the curve" (Figure 3) $[1-3,5]$.

\section{HOW DO WE CONTROL SARS-CoV-2?}

Currently, the best measures to prevent infection with SARS-CoV-2 are good hygiene, including washing our hands with soap regularly, sneezing into a paper tissue (and throwing it away afterwards), and sneezing into our elbows. Good ventilation of rooms is also important. Social distancing (also called physical distancing), which means keeping a distance of at least $1.5 \mathrm{~m}$ from others, is important because it also prevents the virus from spreading. When we cannot keep that distance, wearing masks over the nose and mouth can help prevent the spreading of SARS-CoV-2 (Figure 3) [1, 2].

Never before have scientists worldwide collaborated so closely-at a safe distance!-to find a way to help people with SARS-CoV-2 and to stop its spread. By means of quick testing with a nose swab, we can detect infected people and quarantine them for 2 weeks, so they stop infecting others. Further, by tracking down other people who were in contact with the SARS-CoV-2-positive patients and quarantining them too, the risk of further spreading is contained. A different lab test can help determine whether people were infected in the past and have already built immunity against the virus [1,2]. 
Figure 3

We can help to prevent infection with SARS-CoV-2 and from spreading the virus further by good hygiene: washing our hands with soap regularly, sneezing into a paper tissue (and throwing it away afterwards), sneezing into our elbows, ventilating rooms, social distancing (keeping a distance of at least $1.5 \mathrm{~m}$ from others), and wearing masks over the nose and mouth. By doing so, the rate of infections will slow down, and hospitals will be able to help the people who get really ill. This is what is meant by the term "flattening the curve."

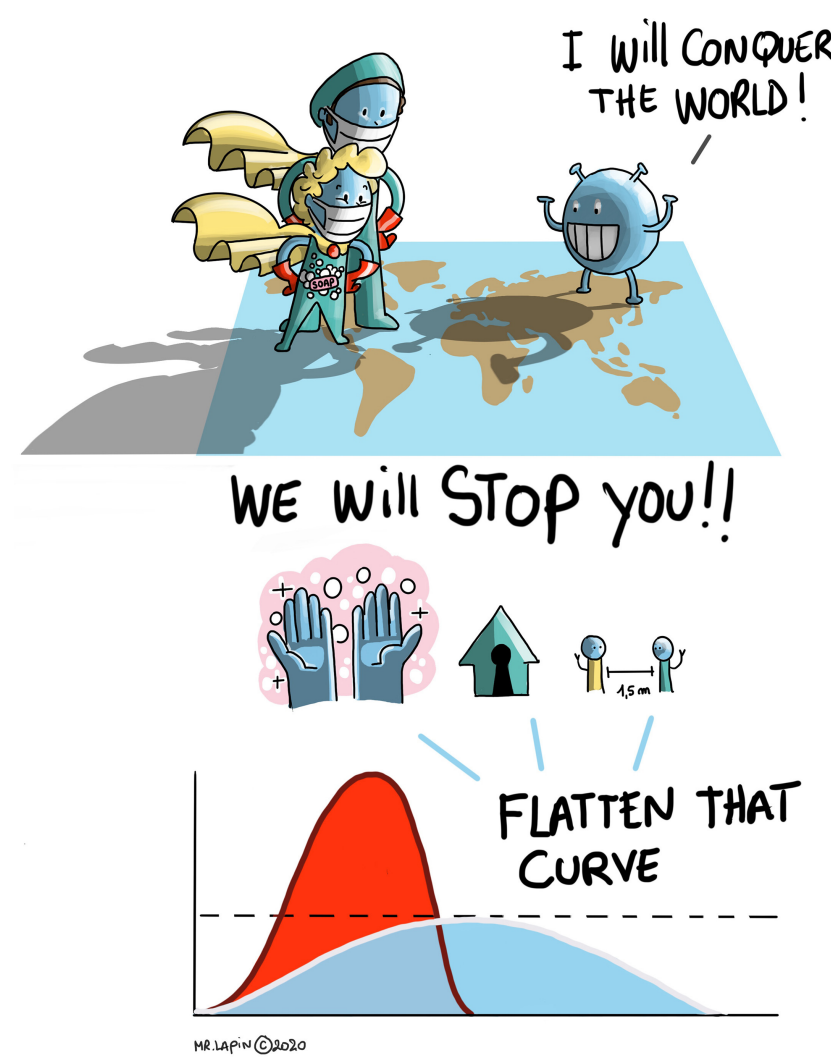

Figure 3

Physicians are also currently exploring ways to relieve patients' symptoms. One way might be by testing drugs that are normally given to patients to fight other infections, to see if they are also effective against SARS-CoV-2 [6]. The blood of people who have recovered from COVID-19 is another potential treatment that is being tested. When fighting the virus, people develop antibodies against it, so their bodies can fight the virus quickly if they encounter it again. Those antibodies (called convalescent serum) can be isolated from the blood and could be given to others to help them fight COVID-19 [1, 2].

\section{AND WHAT ABOUT THE FUTURE?}

A vaccine will be our best chance to protect ourselves against COVID-19. Unfortunately, vaccine development will take at least 1 year. The good news is that there are currently over 165 potential vaccines candidates that are being developed [7].

In the meantime, it is important that each of us continues to fight this virus however we can. SARS-CoV-2 has caused a lot of suffering. Many people got sick, or worse, lost someone they loved. Being quarantined for a long time also caused many people to feel sad and lonely. People could not travel nor go shopping during the lockdown, so the economy also seemed to stop. Consequently, many people lost, or still 
might lose, their jobs. Even when the pandemic is over, it will take some time for the world to recover from the damage caused by SARS-CoV-2. For example, people who lost their jobs need to find other ways to support their families. So, the better we follow the hygiene measures (washing our hands regularly and social distancing), the less the virus will spread and the sooner the pandemic will be over.

\section{REFERENCES}

1. Available online at: https://covid-19.sciensano.be/sites/default/files/Covid19/ COVID-19_fact_sheet_ENG.pdf (accessed July 21, 2020).

2. Wu, D., Wu, T., Liu, Q., and Yang, Z. 2020. The SARS-CoV-2 outbreak: what we know. Int. J. Infect. Dis. 94:44-8. doi: 10.1016/j.ijid.2020.03.004

3. Mallapaty, S. 2020. How do children spread the coronavirus? The science still isn't clear. Nature 581:127-8. doi: 10.1038/d41586-020-01354-0

4. Available online at: https://coronavirus.jhu.edu/ (accessed July 21, 2020).

5. Zimmermann, P., and Curtis, N. 2020. Coronavirus infections in children including COVID-19: an overview of the epidemiology, clinical features, diagnosis, treatment and prevention options in children. Pediatr. Infect. Dis. J. 39:355-68. doi: 10.1097/INF.0000000000002660

6. Ledford, H. 2020. Coronavirus breakthrough: dexamethasone is first drug shown to save lives. Nature 582:469. doi: 10.1038/d41586-020-01824-5

7. https://www.nytimes.com/interactive/2020/science/coronavirus-vaccine -tracker.html (accessed July 21, 2020).

SUBMITTED: 18 May 2020; ACCEPTED: 07 July 2020; PUBLISHED ONLINE: 29 July 2020.

EDITED BY: Michel Goldman, Institute for Interdisciplinary Innovation in Healthcare (I3h), Belgium

CITATION: Stevens H and Neunez M (2020) COVID-19, The Quarantine-Virus Disease. Front. Young Minds 8:102. doi: 10.3389/frym.2020.00102

CONFLICT OF INTEREST: The authors declare that the research was conducted in the absence of any commercial or financial relationships that could be construed as a potential conflict of interest.

COPYRIGHT @ 2020 Stevens and Neunez. This is an open-access article distributed under the terms of the Creative Commons Attribution License (CC BY). The use, distribution or reproduction in other forums is permitted, provided the original author(s) and the copyright owner(s) are credited and that the original publication in this journal is cited, in accordance with accepted academic practice. No use, distribution or reproduction is permitted which does not comply with these terms. 


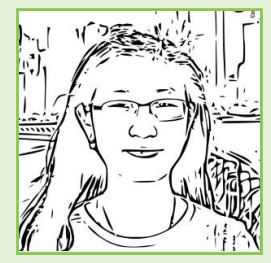

\section{YOUNG REVIEWER}

\section{CAROLINE, AGE: 15}

I am a student and I like the natural sciences. I have two older brothers who are working in science, particularly medicine so I am very interested in knowing more about medical sciences and health related topics. During my free time, I like to read books and eat good food.

\section{AUTHORS}

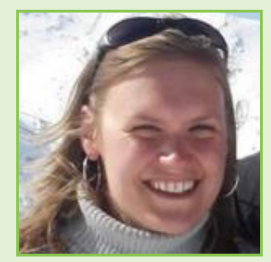

\section{HILDE STEVENS}

I am an Associate Professor at the Université Libre de Bruxelles. My research focuses on how people with various cultures and ways of working (e.g., academics or people in the pharmaceutical industry) could optimally collaborate to bring inventions from the lab to the patient much faster, and how patients in low- and middle-income countries also could get access to innovative therapies. I love telling stories to my children about bad bugs and how to fight them, and then we make paintings about it! *hstevens@i3health.eu

\section{MARIE NEUNEZ}

I am a part-time research fellow at the I3h Institute and Student in Medicine at the Université Libre de Bruxelles (ULB). I was a Clinical Research Coordinator for 2 years in the Departments of Nuclear Medicine $\&$ Radiotherapy at the Institut Jules Bordet (IJB). I also performed a 5-months internship at BASF SE (Mannheim, Germany) in the Human Health \& Nutrition department. I hold a M.Sc. degree in Bioengineering with a specialization in Science, Technology and Quality of Food (UCL, Belgium), a Postgraduate degree in Management (ICHEC Business Management School, Belgium), and a certificate in Clinical Studies (Cefochim, Belgium). 